\title{
Antibiofilm effect of Theobroma cacao (cacao pod) extract on Aggregatibacter actinomycetemcomitans biofilm in vitro
}

\author{
Ciptadhi Tri Oka Binartha, Yessica Puspita Kardinal, Armelia Sari Widyarmann* \\ Department of Microbiology, Faculty of Dentistry, Trisakti University, Jakarta, Indonesia
}

\begin{abstract}
Successful of periodontal treatment is to eradicate biofilm of bacteria. Aggregatibacter actinomycetemcomitans is a Gramnegative bacterium that have been suggested to be the main causes of periodontal disease. Theobroma cacao (cacao pod) is a medicinal plant that has a broad range of pharmacological effects. The aim of this study was to assess the antibiofilm effect of cacao pod extract against $A$. actinomycetemcomitans biofilm in vitro. $A$. actinomycetemcomitans were cultured in Brain Heart Infusion broth. Crystal-violet staining in biofilm assays were used to evaluate the cacao pod extract effect on A. actinomycetemcomitans ATCC 33384 biofilms and $0.2 \%$ chlorhexidine-gluconate was used as a positive control. After 24 hours of incubation, the optical density of each well in microtiter plates was measured. The results showed that the biofilm density after incubation with the cacao pod extract was significantly decreased in all concentrations and all incubation times $(\mathrm{p}<0.05)$. The most effective concentration for inhibiting biofilm A. actinomycetemcomitans was $100 \%$ cacao pod extract and $3 \mathrm{hrs}$ of incubation time $(\mathrm{p}<0.05)$ with a $98.9 \%$ reduction of biofilm compared to negative control. Cacao pod extract is effective in inhibiting the growth of $A$. actinomycetemcomitans biofilm.
\end{abstract}

Keywords: Aggregatibacter actinomycetemcomitans, biofilm, cacao pods

\section{Introduction}

According to the World Health Organization (WHO), one of the main health issues in South East Asia is related to oral and dental health (WHO, 2009). The prevalence of oral and dental disease in South East Asia in 2009 was $32-37 \%$ (WHO, 2009). The most common oral and dental diseases are dental caries and periodontal disease. In particular, based on the 'Survei Kesehatan Rumah Tangga', the prevalence of periodontal disease in Indonesia is $60 \%$ (Badan Penelitian dan Pengembangan Kesehatan RI,
Received:

9 December 2020

Revised:

2 February 2021

Accepted:

28 February 2021

Published Online:

28 February 2021

\section{How to cite this article:}

Binartha, C. T. O. ., Kardinal, Y. P. ., \& Widyarman, A. S. Antibiofilm effect of Theobroma cacao (cacao pod) extract on Aggregatibacter

actinomycetemcomitans

biofilm in vitro. IIUM Journal of Orofacial and Health Sciences, 2(1). 46-55. https://doi.org/10.31436/ijoh s.v2i1.60

\section{Article DOI:}

https://doi.org/10.31436/ijohs. $\underline{\mathrm{v} 2 \mathrm{i} 1.60}$

\section{Corresponding author:}

Address:

Department of Microbiology, Faculty of Dentistry, Trisakti University, Jakarta, Indonesia.

Email address:

armeliasari@trisakti.ac.id 
bacteria, such Pophyromonas gingivalis, Campylobacter spp., Tannerella forsythia, Treponema denticola and $A$. actinomycetemcomitans, will increase and contribute to periodontal inflammation (Duerden, 1991; Radita et al., 2019; Widyarman et al., 2018). A. actinomycetemcomitans is a main etiology in periodontitis (Mättö et al., 1997) and also an obligate anaerobic Gram-negative bacterium (Fine et al., 2007; Perace et al.,1996).

During a caries activity, the bacterial product interacts with gingival epithelial and penetrates into the fibroblast, periodontal ligament and alveolar bone (Lafaurie et al., 2007; Setiawati, 2012). The bacteria attach to one another on a solid surface coated by the matrix, which consists of polysaccharide, extracellular DNA (eDNA) and protein, known as biofilm (Wei et al., 2013). Biofilm can be a main etiology of virulence factors in tooth damage, periodontal disease and systemic disease because of the pathogenic bacteria in oral biofilm (Li et al., 2000). During a caries activity, the bacterial product interacts with gingival epithelial, this is some examples of the pioneering bacteria that attach to dental surfaces and oral mucosa (Huang et al., 2011).

There are some treatments for controlling oral hygiene, such as diet and plaque control, which balance the normal flora in the oral cavity. Plaque control can be performed mechanically and chemically. Mechanical plaque control can be performed using conventional methods, such as tooth brushing and dental flossing, however these methods are incapable of removing plaque accumulation on certain parts, such as the gingival sulcus (Cobb, 2008). The disadvantages of conventional methods can be overcome by combining them with chemical methods such as mouth wash (Wolf et al., 2005). The chemical materials in mouth rinse are phenol, hexetidine, flour and chlorhexidine. The disadvantages of chemical materials for long-term use are tooth discoloration and allergies (Suhag et al., 2007).
Contemporary society chooses to lead a natural lifestyle. This can be seen in the many uses of plants as medicines, which play an important role in life. WHO exemplifies this "back to nature" concept by recommending the use of traditional medicine to preserve health and prevent disease in society (WHO, 2005). Contemporary society chooses to lead a natural lifestyle. Phytopharmacology is a medicine originally made from natural ingredients, which has a certain utility (Dewoto, 2007).

One phytopharmacological material in Indonesia is cacao (Theobroma cacao). Cacao production in Indonesia reaches the third largest in the world (Pusat Penelitian Kopi dan Kakao Indonesia, 2010). Cacao produces seeds and releases $75 \%$ of wastes, such as the cacao pod (Figure 1). This large amount of cacao pod waste becomes a problem for the environment (Sartini et al., 2012). Cacao pods consist of flavonoids, such as anthocyanin, catechin and leukoanthocyanidine, which are bioactive compounds that have antibacterial agent (Mulyatni et al., 2012). Moreover, other compounds in the cacao pod are pectin and lignin. These compounds can potentially be developed into alternative medicines, food supplements and even cosmetics (Armiati et al., 2016; Hii et al., 2009).

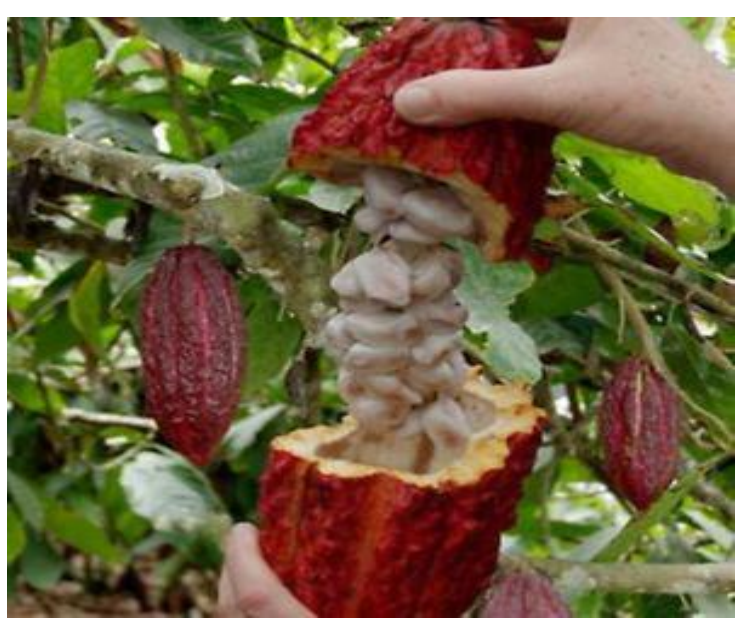

Figure 1. Theobroma cacao 
Previous studies have suggested that antibacterial activity on the cacao pod extract used on Streptococcus mutans, Escherichia coli, Bacillus subtilis and Staphylococcus aureus has shown cacao pod extract potential for inhibiting bacterial growth (Monty, 2006). Cytotoxicity test results on cacao pod extract showed that the cacao pod is nontoxic (Yuanita, 2017). Cocoa has significant antibacterial effects against periodontal pathogenic bacteria such as Porphyromonas gingivalis, Fusobacterium nucleatum, and Prevotella intermedia (Hirao et al., 2010). Consuming a cocoa-enriched diet could diminish periodontitis-induced oxidative stress (Tomofuji et al., 2009). A research on cocoa beans (Theobroma cacao $L$ ) extracted with the ethanol $70 \%$ shows a higher antimicrobial activity against $A$. actinomycetemcomitans than with water (Atikah et al., 2016).

There are many studies regarding the antibacterial effectiveness of cacao pod extract towards bacterial growth, but there is no research on the anti-biofilm activity in cacao pod extract towards $A$. actinomycetemcomitans. Therefore, antibiofilm activity tests of cacao pod extract towards $A$. actinomycetemcomitans (the etiology bacteria in periodontal disease) are needed. Indonesian people are expected to use scientifically tested natural ingredients to prevent periodontal disease. The aim of this research is to analyze the ability of cacao pod extract to inhibit $A$. actinomycetemcomitans biofilm growth in vitro.

\section{Materials and methods}

\section{Cacao extract preparation}

One kilogram of ripe cacao was taken from the tree, and the cacao pod was separated from the seed and placenta. The cacao pod was washed under running water, cut with a knife and dried in the sun. The dried cacao pod was blended and sifted using a 60 -mesh strainer until the pod became powder and known as the sample. The purpose of making this cacao pod powder was to destruct the structural cell and tissue, thus the extract would be easily exposed to the solvent. Cacao pod extraction was performed using the maceration technique. In an Erlenmeyer tube, $40 \mathrm{~g}$ of cacao pod powder and $400 \mathrm{ml}$ of $70 \%$ ethanol were mixed. The Erlenmeyer tube was inserted into a shaker and shaken at $120 \mathrm{rpm}$ at room temperature for 3 hours and then left for 12-15 hours. Moreover, the solution was filtered with Whatman No. 41 filter paper (Merck, Darmstadt) until filtrate in solid residue form was obtained. Final the filtrate with ethanol was inserted into a rotary evaporator to vaporize the solvent, and the concentrated cacao pod extract was obtained. The concentrated cacao pod extract was diluted in concentrations of $6.25 \%, 12.5 \%, 25 \%, 50 \%$ and $100 \%$.

\section{Phytochemical screening}

Qualitative phytochemical analysis was to identify active compound of the ethanol extracts of cacao pod. The extracts were tested for the presence of alkaloids, saponins, tannins, phenolics, flavonoids, triterpenoids, steroids, and glycosides. The qualitative results are expressed as (+) for the presence and (-) for the absence of phytochemicals.

\section{Test for alkaloid}

For Mayer's test, cacao pod extract was mixed with Mayer's reagent (potassium mercuric iodide solution). The creamish color precipitate was formed, indicate the presence of alkaloids.

\section{Test for saponin}

For foam test, $1 \mathrm{~g}$ powder was mixed with 5 $\mathrm{mL}$ of distilled water and shaken for $10 \mathrm{~min}$, Appearance of foam indicate the presence of saponins.

\section{Test of tannins and phenols}

For ferric chloride test, the crude extract was mixed with ferric chloride reagent $\left(\mathrm{FeCl}_{3}\right)$, Blue green colour appeared the presence of tannins.

Test flavonoids 
For Shinoda test, cacao pod crude extract was mixed with a few of magnesium ribbon and hydrochloric acid. Occurrence of a pink, orange or red coloration indicate the presence of flavonoids.

\section{Test for steroid and triterpenoid}

For Liebermann-Burchard test, cacao pod crude extract was mixed with acetic anhydride boiled and cooled, few drops of $\mathrm{H}_{2} \mathrm{SO}_{4}$ were added down from the side of the test tube. Blue green ring which showed the presence of steroid and the formation red colour indicate the presence of triterpenoids.

\section{Test for glycoside}

For Salkowski's Test, cacao pod crude extract was mixed with chloroform, then added concentrated sulfuric acid were added and shaken. Brown red colour indicate the presence of glycosides.

\section{A. actinomycetemcomitans culture}

A. actinomycetemcomitans ATCC 33384 is an obligate anaerobic Gram-negative bacterium. The bacterial culture was performed in an anaerobic atmosphere $5 \%$ $\mathrm{CO}_{2}$ ) on AaGM (A. actinomycetemcomitans growth medium) in a petri dish and incubated for 24 hours at $37^{\circ} \mathrm{C}$.

\section{Biofilm assay}

The A. actinomycetemcomitans culture was transferred to $25 \mathrm{ml}$ of Brain Heart Infusion broth (Oxoid, Hampshire, UK) and incubated for 24 hours at $37^{\circ} \mathrm{C}$ in an anaerobic atmosphere. The culture was then homogenized with a vortexer, and the bacterial colony growth was measured with a $450 \mathrm{~nm}$ wavelength. Optical density was measured with a microplate reader (SAFAS MP96, SAFAS, Monaco), and the result was OD $0.132\left(1 \times 10^{7} \mathrm{CFU} / \mathrm{ml}\right)$. A $200 \mu \mathrm{L}$ culture was distributed into 96 well-plate microplates and incubated at $37^{\circ} \mathrm{C}$ for 48 hours in an anaerobic atmosphere to form the biofilm. The supernatant was removed, and the well was rinsed twice with $200 \mu \mathrm{L}$ Phosphate Buffered Saline (PBS). $200 \mu \mathrm{L}$ of cacao pod extract in different concentrations $(100 \%, 50 \%, 25 \%, 12.5 \%$ and $6.25 \%)$ were distributed into biofilm containing plates. The extract was incubated at $37^{\circ} \mathrm{C}$ for $15 \mathrm{~min}$, 1 hour, 3 hours, or 6 hours in an anaerobic atmosphere, and the inhibition effect was observed. The supernatant was removed, and the well was rinsed twice with $200 \mu \mathrm{L}$ PBS. Crystal violet $(0.5 \% \quad \mathrm{w} / \mathrm{v})$ was distributed into the well-plate and incubated for $15 \mathrm{~min}$. The extraction from violet crystal in the well-plate was measured as a biofilm number with the addition of $200 \mu \mathrm{L}$ of ethanol absolute (Merck, Darmstadt) for 15 min, and the absorbance was measured with $490 \mathrm{~nm}$ wavelength. The biofilm without the cacao pod extract was used as a negative control, and $0.2 \%$ chlorhexidine was used as a positive control. All treatments were done in triplicate.

\section{Data analysis}

The data was analyzed using a parametric test method with the Saphiro-Wilk normality test. An ANOVA one-way statistical test was performed for normally distributed data. A Tukey-HSD test was performed to determine the significant differences. $\mathrm{p}<0.05$ was considered significant.

\section{Results}

\section{Preliminary qualitative phytochemical screening analysis}

The present study's findings demonstrate that the ethanol extract of cacao pod extract contained alkaloids, saponins, phenolics, flavonoids, triterpenoids, and glycosides, but not tannins or steroids (Table 1).

Table 1 . The phytochemicals test result of cacao pod extract

$\begin{array}{ll}\text { Phytochemical test } & \text { Results } \\ \text { Alkaloid } & + \\ \text { Saponin } & + \\ \text { Tanin } & - \\ \text { Phenolics } & + \\ \text { Flavonoid } & + \\ \text { Triterpenoid } & + \\ \text { Steroid } & - \\ \text { Glycosides } & +\end{array}$




\section{The inhibitory effects of cacao pod extract against biofilm formation}

The results showed that the biofilm density after incubation with the cacao pod extract was significantly decreased in all concentrations and all incubation times $(p<0.05)$. The most effective concentration for inhibiting biofilm $A$. actinomycetemcomitans was $100 \%$ cacao pod extract and 3 hours of incubation time $(p<0.05)$ with a $98.9 \%$ reduction of biofilm compared to negative control (Figure 2-5).

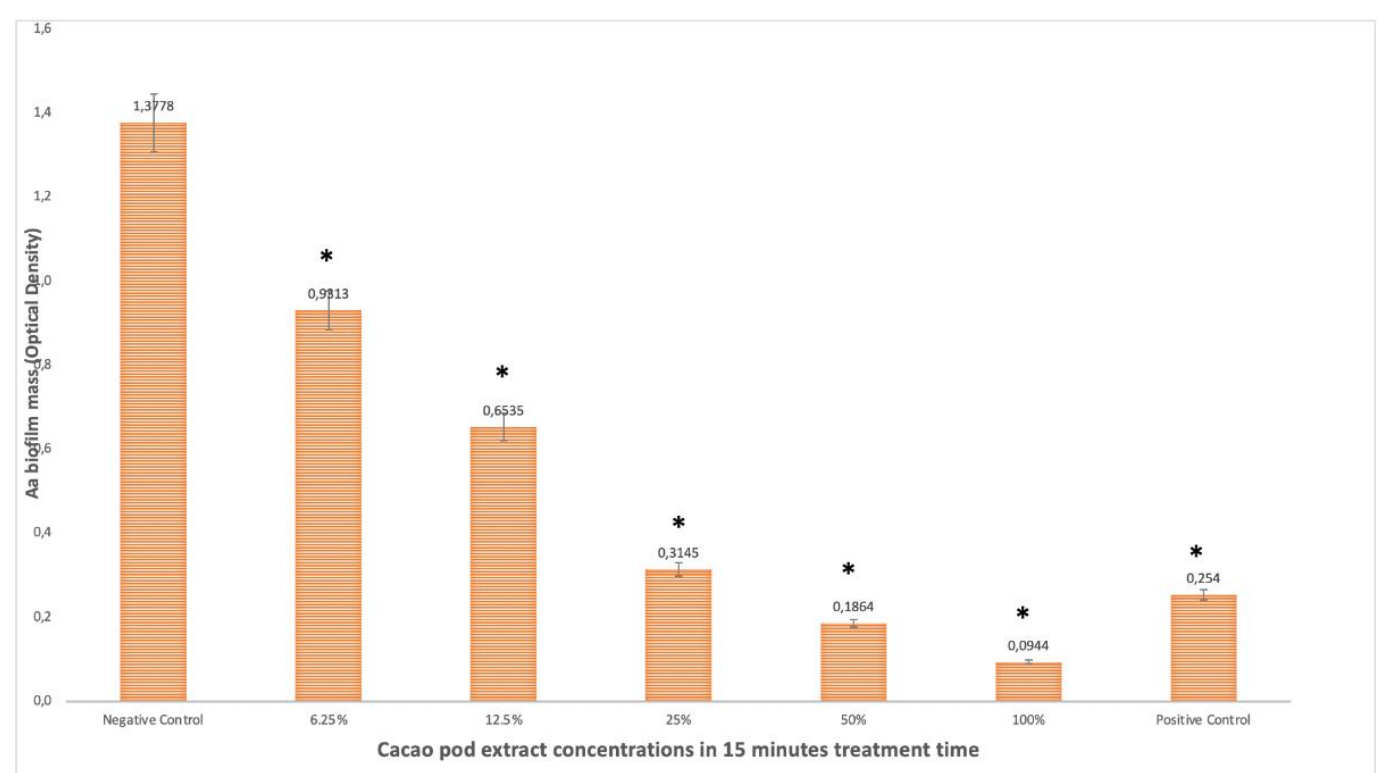

Figure 2. The reduction graphic of $A$. actinomycetemcomitans biofilms (as measured by optical density) after 15 minutes application of cacao pod extract $(6.25 \%, 12.5 \%, 25 \%, 50 \%, 100 \%)$, compared to negative and positive controls. Biofilm without treatment was used as a negative control and chlorhexidine gluconate $(0.2 \%)$ as a positive control. All treatments were done in triplicate. $\left({ }^{*} \mathrm{p}<0.05\right.$ compared to the negative control)

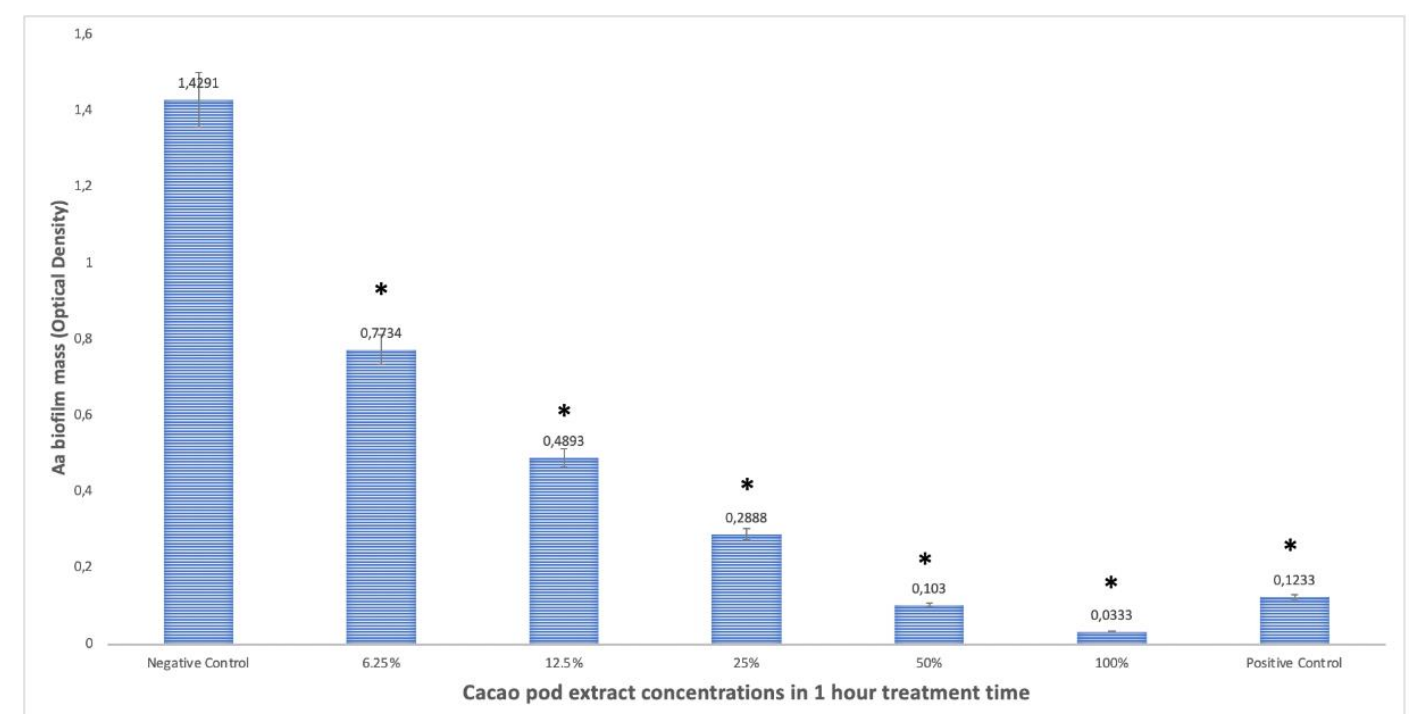

Figure 3. The reduction graphic of A. actinomycetemcomitans biofilms (as measured by optical density) after 1-hour application of cacao pod extract $(6.25 \%, 12.5 \%, 25 \%, 50 \%, 100 \%)$, compared to negative and positive controls. Biofilm without treatment was used as a negative control and chlorhexidine gluconate $(0.2 \%)$ as a positive control. All treatments were done in triplicate. $\left({ }^{*} \mathrm{p}<0.05\right.$ compared to the negative control) 


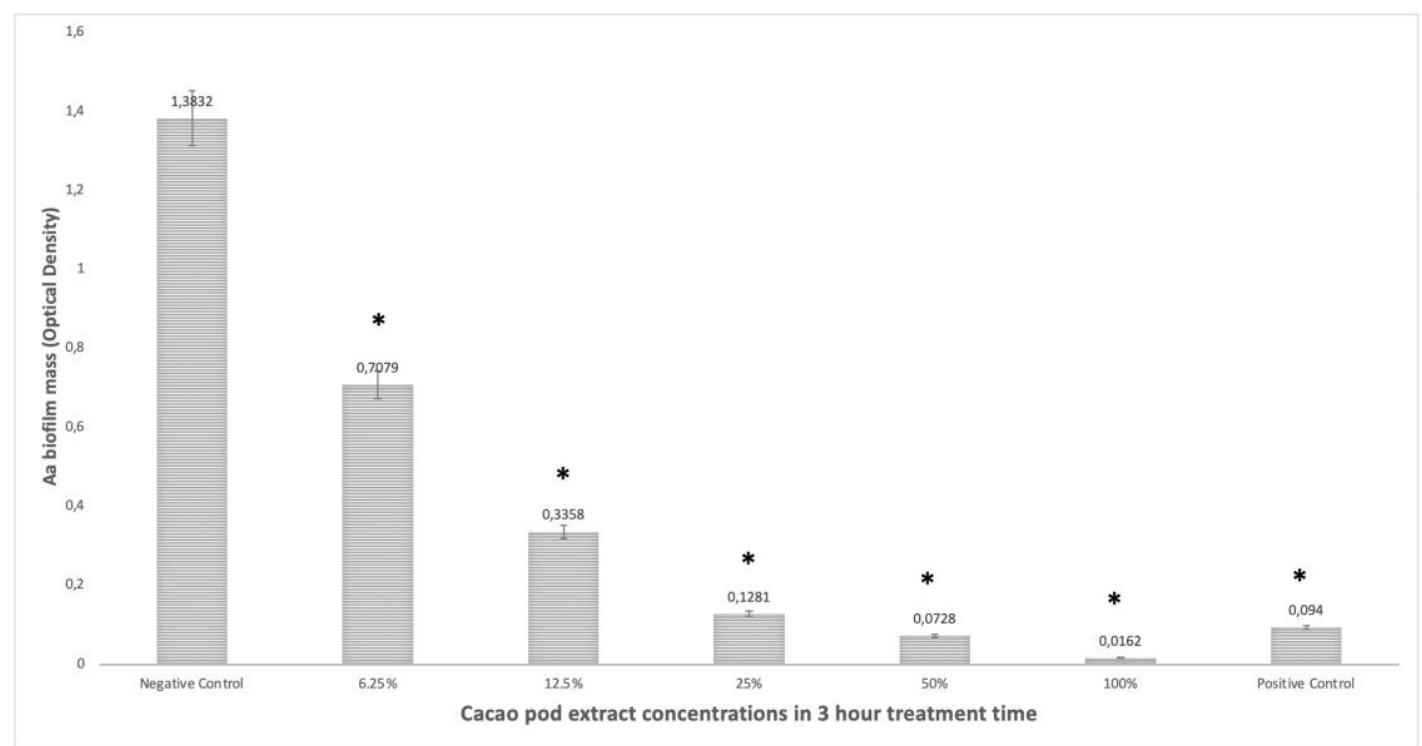

Figure 4. The reduction graphic of A. actinomycetemcomitans biofilms (as measured by optical density) after 3-hour application of cacao pod extract $(6.25 \%, 12.5 \%, 25 \%, 50 \%, 100 \%)$, compared to negative and positive controls. Biofilm without treatment was used as a negative control and chlorhexidine gluconate $(0.2 \%)$ as a positive control. All treatments were done in triplicate. $(* \mathrm{p}<0.05$ compared to the negative control)

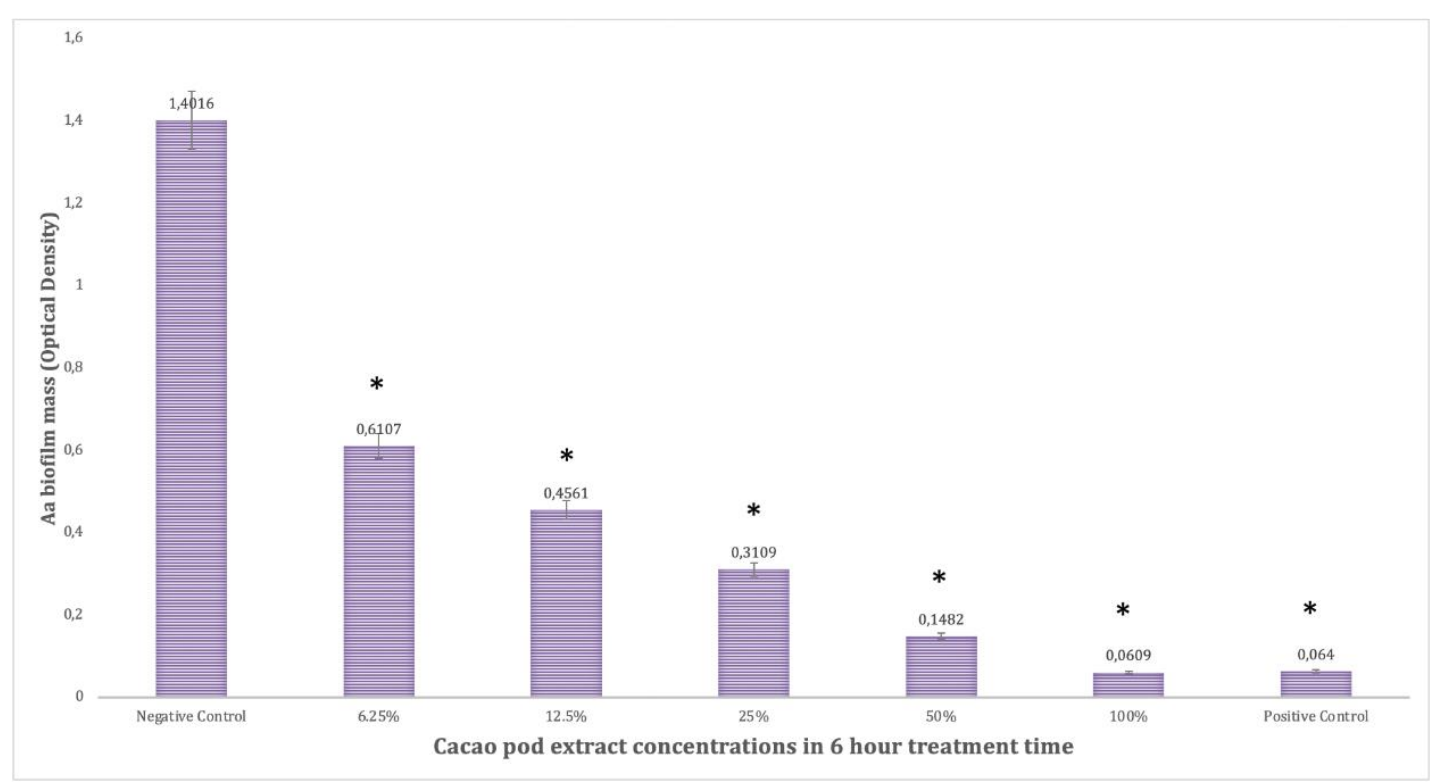

Figure 5. The reduction graphic of A. actinomycetemcomitans biofilms (as measured by optical density) after 6-hour application of cacao pod extract $(6.25 \%, 12.5 \%, 25 \%, 50 \%, 100 \%)$, compared to negative and positive controls. Biofilm without treatment was used as a negative control and chlorhexidine gluconate $(0.2 \%)$ as a positive control. All treatments were done in triplicate. $\left({ }^{*} p<0.05\right.$ compared to the negative control)

\section{Discussion}

Biofilm-associated periodontitis disease is a major causes of tooth loss in oral cavity dental cases. The primary etiologies factor is bacterial form microcolonies known as biofilm. biofilms were found to protect from to harm environmental and low nutrient condition (Berezow \& Darveau, 2012). Choosing appropriate treatment is the important factor of successful in periodontitis treatment. Beside scaling and root planning as the primary therapy, use antiseptics therapy is the common choice for treating periodontitis. 
Many of studies on the efficacy of synthetic medicine such as antiseptics have been established. Antiseptics are often used as adjunctive medicine with scaling and root planing. One of the antiseptics meterial for periodontitis treatment is chlorhexidine (CHX), CHX has been known as the gold standard of oral antiseptics (Mathur et al., 2011). Studies reported that use of $0.2 \%$ chlorhexidine had antibacterial effects on $\mathrm{A}$. actinomycetemcomitans (Kadkhoda et al., 2016). CHX was also more effective than minocycline at killing P. gingivalis biofilm in vitro (Noiri et al., 2003). The mechanism of action of CHX is to destroying bacterial proteins and cell wall. (De Wall et al., 2013). But there are some side effects of CHX, such as discolouration of teeth, tongue (distorted taste), allergic and cytotoxic effect. In vitro study of CHX to gingival cells showed that the toxic potency of CHX (Babic et al., 1995). Various allergic reaction due to CHX have been showed such as desquamative gingivitis, dermatitis, urticaria and occupational asthma (Dukes, 1992; Krauthheim, 2004).

Herbal medicines are generally considered to be safe and effective compare to synthetic medicines. About $8 \%$ of hospital admission in USA are due to adverse effects of synthetic drugs. At least 100,000 people each year die due to toxicities effect of synthetic drugs (Philomena, 2011). Herbal medicines contain various of active compounds that useful for health such as antioxidant activities, antibacterial, anti-inflammation and anti-cancer (Rafieian-Kopaie et al., 2011; Shirzad et al., 2011). One of the herbal medicines is cacao pod. The cacao pod has anti-inflammatory, antioxidant and antimicrobial material. The antimicrobial compound in cacao pods is flavonoid. The flavonoids in cacao pods are catechin, anthocyanin and leukoanthocyanidine (Mulyatni et al., 2012). Flavonoids are phenolic compounds and the result of phenylpropanoid cycle synthesis as a response against microbial infection. Flavonoids work by reducing the fluidity of the bacterial cell membrane. The flavonoids in the cacao pod have been proven to inhibit Streptococcus mutans, Escherichia coli, Bacillus subtilis and Staphylococcus aureus
(Hii et al., 2009). The cacao pod is nontoxic (Armiati et al., 2016), and other compounds that can be found in the cacao pod include pectin and lignin (Hii et al., 2009).

Biofilm assay will provide information about the quantification of biofilm bacteria. This colorimetric assay is a semi-quantitative method based on dye (crystal violet) uptake by the bacteria cell in a biofilm. The biofilm assay analysis of this research is supported by other research which states that dried ethanol cacao pod extract with a $20 \%$ concentration has antibacterial effects against Escherichia coli, Salmonella typhosa, Staphylococcus aureus and Streptococcus mutans. The inhibition zones were $8.15 \mathrm{~mm}$, $8.25 \mathrm{~mm}, 9.15 \mathrm{~mm}$ and $8.95 \mathrm{~mm}$, respectively. Other research has shown that the potential of cacao pod extract to inhibit bacterial growth in the urinary tract and that the higher the extract concentration, the larger the inhibition zone against bacterial growth. The largest inhibition zone of Staphylococcus aureus and Escherichia coli growth was formed at a $64 \%$ concentration, and the result was $10 \mathrm{~mm}$ and $8.83 \mathrm{~mm}$, respectively (Mulyatni et al., 2012).

Other research has shown that there was a reduction in optical density (OD) in 4 hours and 24 hours of incubation time at a 30\% concentration against Streptococcus mutans, and this research also showed that cacao pod extract can reduce the acid production of Streptococcus mutans (Monty, 2006). Research by Yuanita et al. in 2017 stated that cacao pod extract in $100 \%, 50 \%, 25 \%$, $12.5 \%, 6.25 \%$ and $3.25 \%$ concentrations was able to reduce the optical density of Enterococcus faecalis biofilm; however, a concentration lower than a $3.25 \%$ was unable to reduce the density of Enterococcus faecalis (Yuanita, 2017).

Based on phytochemical tests at the Laboratorium Balai Penelitian Tanaman Rempah dan Obat (BALITRO), cacao pod extract consists of flavonoid, anthocyanin, catechins, saponin, lignin, pectin and triterpenoid. Flavonoid compounds consist of polyphenol with a benzo-y-pyrone chemical structure. Flavonoid has the ability, as an antibacterial, to reduce bacterial 
enzymes, interfering with protein transport in the bacterial cell membrane and destructing the bacterial cell membrane (Chandki et al., 2011; Rose et al., 2004).

The glycoside on cacao pod extract is saponin. Saponins are able to destruct the cytoplasm membrane and affect the permeability of the bacterial cell membrane, so the exchange of material inside or outside is uncontrollable. Saponin also has a pharmacological role as a cough suppressant, an anti-inflammatory, a vasoprotective, a hipocolestrolemic, an immune-modulator, an antifungal and an anti-parasite (Ahman, 2017; Podolak et al., 2010). Anthocyanin is a coloring compound in the cacao pod. Catechins are compounds that act as antioxidants, and lignin and pectin are the main components of cell and structural composition in cacao pod tissue (Karatan et al., 2009). Another compound in the cacao pod is triterpenoid, which is a hydrocarbon component $\left(\mathrm{C}_{5} \mathrm{H}_{8}\right)$ that gives a distinctive odor to some parts of the plant, such the flower, fruit, leaf and branch. Triterpenoid also has an antimicrobial agent (Sawai et al., 2011).

With these results herbal medicines have potential as antibiofilm agents and many people every year turn to herbal medicines from synthetic medicines because they believe herbal medicines have low side effects (Kazemipoor et al., 2012). Many studies investigated antibiofilm effects of herbal products on bacterial biofilm suggesting their ability as alternative agents for bacterial infection.

\section{Conclusion}

Based on this research, it can be concluded that cacao pod extract has an inhibitory effect on the growth of $A$. actinomycetemcomitans biofilm and prevents periodontal disease, especially aggressive periodontitis. The higher the concentration of cacao pod extract, the greater the inhibitory effect on the biofilm viability of $A$. actinomycetemcomitans. Further study to observe cacao pod use as an effective anti-biofilm in the oral cavity is still needed. In vivo research is warranted to observe the side effects of cacao pod use.

\section{Acknowledgement}

This research was performed in Laboratorium Balai Penelitian Tanaman Rempah dan Obat (Balittro) and in the Microbiology Center of Research and Education (MiCORE) laboratory of the Dentistry Faculty at Trisakti University.

\section{References}

Ahman, S. (2017) Pharmacognosy: Introduction of plant constitents and their tests. New Delhi: Department of Pharmacognosy and Phytochemistry, Faculty of Pharmacy. July. p 1-10.

Armiati, Leman, M.A., Waworontu, O.A. (2016). Uji efek antibakteri ekstrak kulit biji kakao (Theobroma cacao) terhadap bakteri Streptococcus mutans. Journal Ilmah Farmasi, 5:20-24.

Atikah, A. R., Budi, H. S., Kusumaningsih, T. (2016). Antibacterial effects of $70 \%$ ethanol and water extract of cacao beans (Theobroma cacao L.) on Aggregatibacter actinomycetemcomitans. Dental Journal, 49(2), 104-109.

Babich, H., Wurzburger, B.J., Rubin, Y.L., Sinensky, M.C., Blau, L.(1995). An in vitro study on the cytotoxicity of chlorhexidine digluconate to human gingival cells. Cell Biology and Toxicology, 11, 79-88.

Badan Penelitian dan Pengembangan Kesehatan Kementrian Kesehatan RI. (2009) In: Laporan SKRT: Studi Morbiditas dan Disabilitas, 2007. p 32.

Berezow, A.B., Darveau, R.P. Microbial shift and periodontitis (2011). Periodontology 2000, 55(1), 36-47.

Chandki, R., Banthia, P., Banthia, R. (2011) Biofilms: A microbial home. Journal of Indian Society of Periodontology, 15(2), 111-114.

Cobb, C.M. (2008). Microbes, inflammation, scaling and root planning, and the periodontal condition. Journal of Dental Hygiene, 82(Suppl 3),4-9.

De Waal, Y., Raghoebar, G., Huddleston, S.J., Meijer, H., Winkel, E., van Winkelhoff, A. (2013). Implant decontamination during surgical peri-implantitis treatment: A randomized, double-blind, placebocontrolled trial. Journal of Clinical Periodontology, 40,186-195.

Dewoto, H.R. (2007). Pengembangan obat tradisional Indonesia menjadi fitofarmaka. Majalah Kedokteran Indonesia. 57(7), 205-211.

Duerden, B.I., Drasar, B.S. (1991). Anaerobes in Human Disease. Wiley-Liss, New York.

Dukes, M.N.G. (1992). Meyler's Side Effects of Drugs: An Encyclopedia of Adverse Reactions and Interactions. Amsterdam: Elsevier: pp. 576-9.

Fine, D.H., Markowitz, K., Furgang, D., Fairlie, K., Ferrandiz, J., Nasri, C. et al. (2007). Aggregatibacter actinomycetemcomitans and its 
relationship to initation of localized aggressive periodontitis: longitudinal cohort study of initially healthy adolescents. Journal of Clinical Microbiology. 45(12), 3859-3869.

Haynes, W.G., Stanford, C. (2014). Periodontal disease and atherosclerosis: from dental to arterial plaque. Journal of The American Heart Association, 23, 1309-1311.

Hii, C.L., Law, C.L., Suzannah, S., Misnawi, Cloke, M. (2009). Polyphenols in cocoa (Theobroma cacao). Asian Journal of Food and Agro-Industry. 2,702-704.

Hirao, C., Nishimura, E., Kamei, M., Ohshima, T., Maeda, N. (2010). Antibacterial effects of cocoa on periodontal pathogenic bacteria. Journal of Oral Biosciences, 52(3), 283-291.

Huang, R., Li, M., Gregory, R.L. (2011) Bacterial interactions in dental biofilm. Virulence, 2(5), 435-444.

Kadkhoda, Z., Amarlu, Z., Eshraghi, S., Samiei, N. (2016). Antimicrobial effect of chlorhexidine on Aggregatibacter actinomycetemcomitans biofilms associated with peri-implantitis. Journal of Dental Research, Dental Clinic and Dental Prospects, 10(3),176180.

Karatan, E., Wattrick, P. (2009) Signals, regulatory networks, and materials that build and break bacterial biofilms. Microbiology and Molecular Biology Reviews, 73(2), 310-347.

Kazemipoor, M., Radzi, C.W., Cordell, G.A., Yaze, I. (2012) Safety, efficacy and metabolism of traditional medicinal plants in the management of obesity: A review. International Journal of Chemical Engineering, 4, 288-292.

Krautheim, A.B., German, T.H.M, Bircher, A.J. (2004). Chlorhexidine anaphylaxis: case report and review of the literature. Contact Dermatitis, 50,113-116.

Lafaurie, G.I., Conteras, A., Baron, A., Botero, J., Mayorga-Fayad, I., Jaramillo, A. et al. (2007) demographic, clinical, and microbial aspects of chronic and aggressive periodontitis in Colombia: A multicenter study. Journal of Periodontology. 78(4), 629-639.

Li, X., Kolltveit, K.M., Tronstad, L., Olsen, I. (2000) systemic diseases caused by oral infection. Clinical Microbiology Review, 13(4), 547-558.

Mathur, S., Mathur, T., Srivastava, R., Khatri, R. (2011). Chlorhexidine: The gold standard in chemical plaque control. National Journal of Physiology, Pharmacy and Pharmacology,1,45-50.

Mättö, J., Asikainen, S., Vaisanen, M.L., Rautio, M., Saarela, M., Summanen, P., Finegold, S., Jousimies-Somer, H. (1997). Role of Aggregatibacter actinomycetemcomitans in extraoral and some odontogenic infections. Clinical Infection Disease, 25, S194S198.

Monty, S. (2006). The effect of cocoa polyphenols on the growth, metabolism, and biofilm formation by Streptococcus mutans and Streptococcus sanguinis. The European Journal of Oral Sciences, 114(4),343-8.

Mulyatni, A.S., Budiani, A., Taniwiryono, D. (2012). Aktivitas antibakteri ekstrak kulit buah kakao
(Theobroma cacao) terhadap Streptococcus mutans, Escherichia coli, Bacillus subtilis, dan Staphylococcus aureus. Indonesia Journal of Biotechnology Research on Estate Crops, 80,7784.

Perry, D.A. Periodontal diseases. (2014). In Periodontology for the Dental Hygienist. $4^{\text {th }}$ Edition John Dolan. Missouri: Saunders Elsevier. pp. 88-111.

Noiri, Y., Okami, Y., Narimatsu, M., Takahashi, Y., Kawahara, T., Ebisu, S. (2003). Effects of chlorhexidine, minocycline, and metronidazole on Porphyromonas gingivalis strain 381 in biofilms. Journal of Periodontology, 74,16471651.

NL, R. (2005). Oral health and systemic health. Minnesota Medicine, 88(8), 46-48.

Pearce, M.A., Dixon, R.A., Gharbia, S.E., Shah, H.N., Devine, D.A. (1996). Characterization of Aggregatibacter actinomycetemcomitans by enzyme production, restriction endonuclease and ribosomal RNA gene restriction analyses. Oral Microbiology and Immunology,11,135-141.

Philomena, G. (2011). Concerns regarding the safety and toxicity of medicinal plants - An overview. Journal of Applied Pharmaceutical Science, 1(6), 40-44

Podolak, I., Galanty, A., Sobolewska, D. (2010) Saponins as cytotoxic agents: A review. Phytochemistry Review, 9(3), 425-474.

Pusat Penelitian Kopi dan Kakao Indonesia. (2010). Buku Pintar Budi Daya Kakao, Ed1, Jakarta: Agro Media Pustaka.

Radita, D.C., Widyarman, A.S. (2019). Mahkota dewa (god's crown) fruit extract inhibits the formation of periodontal pathogen biofilms in vitro. Journal of Indonesian Dental Association, 2(2),57-62.

Rafieian-Kopaie, M., Baradaran, A. (2013). Plants antioxidants: From laboratory to clinic. Journal of Nephropathology, 2(2),152-153.

Rose, L.F., Mealey, B., Genco, R., Cohen, D.W. (2004) Periodontics: Medicine, Surgery, and Implant. $1^{\text {st }}$ ed USA: Elsevier Mosby.

Sartini, M., Djide, N., Duma, N. (2012). Pemanfaatan limbah kulit buah kakao sebagai sumber bahan aktif untuk untuk sediaan farmasi. Jurnal Industri Hasil Perkebunan,7(2),69-73.

Sawai, S., Saito, K. (2011) Triterpenoid biosynthesis and engineering in plants. Frontiers in Plant Science, 2, 25, 1-8.

Setiawati, E.M. (2012). Crude toxin of Aggregatibacter actinomycetemcomitans derotype-B increase PARP-1 expression in gingival epithelium. Dental Journal, 45(1),39-42.

Shirzad, H., Taji, F., Rafieian-Kopaei, M. (2011). Correlation between antioxidant activity of garlic extracts and WEHI-164 fibrosarcoma tumour growth in BALB/c mice. Journal of Medicinal Food, 14(9),969-974.

Suhag, A., Dixit, J., Dhan, P. (2007). Role of curcumin as a subgingival irrigant. PERIO, 4, 115-121.

Tampubolon, N.S. (2006) Dampak penyakit periodontal terhadap kualitas hidup: Thesis. Universitas Sumatera Utara. 
IIUM Journal of Orofacial and Health Sciences (2021) 2(1): 46-55

Tomofuji, T., Ekuni, D., Irie, K., Azuma, T., Endo, Y., Tamaki, N. et al. (2009). Preventive effects of a cocoa-enriched diet on gingival oxidative stress in experimental periodontitis. Journal of Periodontology, 80(11), 1799-1808.

Wei, Q., Ma, L.Z. (2013). Biofilm matrix and its regulation in Pseudomonas aeruginosa. International Journal of Molecular Science, 14, 20983-20984.

Widyarman, A.S., Suhalim, O.P., Nandary, D., Theodorea, C.F. (2018). Pomegranate juice inhibits periodontal pathogens biofilm in vitro. Scientific Dental Journal. 28,2(3),101-108.

Wolf, H.F., Rateitschak, K.H. (2005). Color Atlas of Dental Medicine: Periodontology, Thieme: New York.
World Health Organization (2005) Traditional Medicine Strategy 2002-2005: Geneva.

World Health Organization (2009) Oral Health Surveys: Basic Methods. $4^{\text {th }}$ ed. Geneva: ORH/EPID.

World Health Organization (2009) Formulating Oral Health Strategy for South-East Asia. New Delhi: World Health Organization. Retrieved from WHO http://www.who.int/iris/handle/10665/20511 9

Yuanita, T. (2017) Antibiofilm power of cocoa bean pod husk extract (Theobroma Cacao) against Enterococcus Faecalis bacteria (in vitro). International Medical Device and Technology Conference. 1-11. 